\title{
STRATEGI PENGEMBANGAN WISATA TAMAN KOTA BERDASARKAN TIPOLOGI TOURISM AREA LIFE CYCLE UNTUK MENDUKUNG PROGRAM REVITALISASI DI SUNGAI KALIMAS SURABAYA
}

\author{
Pranata, Galih ${ }^{1}$, Wicaksono, Wahyu ${ }^{2}$, Zubaidah, Alfie ${ }^{3}$, dan Idajati, Hertiari ${ }^{4}$ \\ ${ }^{123}$ Urban and Regional Planning Department, Institut Teknologi Sepuluh Nopember \\ Email:ganungp@gmail.com
}

\begin{abstract}
ABSTRAK
Taman wisata di sepanjang Sungai Kalimas Surabaya merupakan taman yang dibangun untuk merevitalisasi kawasan sungai kalimas yang terdegradasi. Terdapat lima taman hasil program revitalisiasi yang dijadikan sebagai destinasi di kawasan Sungai Kalimas diantaranya Taman Wisata Keputran, Taman Wisata BMX \& Skate, Taman Wisata Prestasi, Taman Wisata Ekspresi, dan Taman Wisata Jayengrono. Berdasarkan kriteria Tourism Area Life Cycle (TALC), terdapat dua tipologi tahapan yakni tahap development pada Taman Wisata Prestasi Prestasi, Taman Wisata Ekspresi, dan Taman Wisata Jayengrono serta tahap consolidation pada taman Taman Wisata Keputran, Taman Wisata BMX \& SkateAgar seluruh taman wisata tersebut dapat berada pada kondisi yang optimum serta mengantisipasi masuknya taman pada tahap yang menyebabkan degradasi lingkungan, maka penelitian ini bertujuan untuk merumuskan strategi pengembangan wisata taman kota berdasarkan tipologi TALC untuk mendukung program revitalisasi di sungai kalimas dengan metoda analisa SWOT. Hasil dari penelitian ini adalah untuk taman yang berada pada tahap development, strategi pengembangan cenderung pada pengadaan event rutin agar tetap dapat mendatangkan wisatawan tanpa adanya peremajaan atraksi dan sarana rekreasi karena dianggap masih menarik oleh wisatawan. Sedangkan pada tahap consolidation strategi pengembangan cenderung pada peremajaan dan penambahan atraksi baru untuk menambah daya tarik taman wisata serta pengadaan event untuk mendatangkan wisatawan.
\end{abstract}

Kata kunci: Kalimas Surabaya, Strategi Pengembangan, SWOT, Taman Wisata, Tourism Area Life Cycle

\section{PENDAHULUAN}

Dalam dokumen Rencana Penataan dan Revitalisasi Sungai Kalimas (B. P. P. K. Surabaya, 2006) dijelaskan bahwa taman wisata di sepanjang Sungai Kalimas dibangun oleh Pemerintah Kota Surabaya sebagai upaya revitalisasi kawasan Sungai Kalimas yang pernah mengalami degradasi lingkungan. Program yang dilakukan untuk merevitalisasi sungai kalimas diantaranya menciptakan ruang terbuka hijau baru di sepanjang kawasan sungai kalimas dengan kegiatan atraktif secara sosial-ekonomi di badan maupun tepian sungai melalui kegiatan pariwisata. Adapun dalam dokumen Rencana Induk Pariwisata 
Kota Surabaya tahun (D. K. dan P. K. Surabaya, 2017) disebutkan bahwa taman wisata yang dibangun sebagai hasil dari program revitalisasi di sepanjang Sungai Kalimas diantaranya adalah taman Taman Keputran, Taman BMX \& Skate Arena, Taman Prestasi, Taman Ekspresi, dan Taman Jayengrono. Setiap taman wisata yang terbangun memiliki cirikhas dayatarik wisata tersendiri diantaranya arena olahraga BMX dan skateboard yang terdapat di Taman BMX \& Skate Arena, aktivitas menunggangi kuda dan menyewa perahu motor di Taman Prestasi, hiasan taman berupa karya seni patung dari material bekas pada Taman Ekspresi, ornamen relief sejarah untuk mengenang pertempuran 10 november 1945 pada Taman Jayengrono, dan lain sebagainya. Selain adanya kegiatan pariwisata sebagai sarana sosial, untuk menunjang kegiatan ekonomi taman-taman tersebut juga dilengkapi kios kios penjualan seperti sentra Pedagang Kaki Lima (PKL).

Meski telah dibangun dengan cirikhas dayatarik, hasil penelitian (Pranata, 2018) mengenai tourism area life cycle (TALC) taman wisata di sepanjang Sungai Kalimas menunjukkan bahwa terdapat beberapa taman wisata dengan performa yang tidak optimal. TALC (Pitana, 2009) merupakan model yang digunakan untuk memprediksi arah kecenderungan pengembangan pariwisata serta memahami evolusi dan produk pariwisata. Kecenderungan pengembangan pariwisata dalam TALC ditunjukkan melalui tujuh tahapan dalam siklus hidup pariwisata. Ketujuh tahapan tersebut terdiri dari tahap exploration, involvement, development, consolidation, stagnation, declanation, rejuvenation.

Tahap eksploration secara umum adalah tahap dimana destinasi wisata masih baru dikenal, belum ada pembangunan, dan hanya mengandalkan atraksi alami, sehingga jumlah kunjungan masih sedikit. Setelah lebih dikenal destinasi memasuki tahap involvement dimana penduduk sekitar destinasi mulai membangun fasilitas penunjang pariwisata secara sederhana dan tidak resmi yang mengakibatkan jumlah wisatawan mulai meningkat namun tidak signifikan. Seiring semakin dikenal, destinasi memasuki pada tahap development dimana terdapat investor atau yang tertarik untuk membangun dan mengelola destinasi sehingga destinasi dibangun fasilitas, atraksi alami dan buatan yang resmi dan terkonsep, serta pemasaran dilakukan secara intensif. Akibat pembangunan investor tersebut, jumlah wisatawan meningkat signifikan. Setelah tahap development destinasi wisata memasuki tahap consolidation dimana atraksi dan fasilitas dianggap tua dan ketinggalan jaman oleh wisatawan sehingga jumlah kunjungan meningkat namun tidak signifikan. Pada tahap consolidation upaya promosi dilakukan dengan jangkauan yang lebih jauh untuk mendatangkan wisatawan. Apabila pengelola tidak ada tindakan perbaruan destinasi maka destinasi memasuki pada tahap stagnation dimana wisatawan sudah bosan dengan atraksi dan fasilitas sehingga jumlah kunjungan tidak mengalami peningkatan, upaya promosi yang diupayakan juga tidak membuahkan hasil. Apabila pada tahap stagnation juga belum ada perbaikan, destinasi memasuki pada tahap declanation dimana pada tahap ini wisatawan sudah tidak tertarik dengan destinasi dengan atraksi yang tua dan ketinggalan jaman sehingga jumlah kunjungan menurun. Pada tahap ini pengelola sudah tidak berperan mengelola destinasi sehingga penduduk kembali berperan mengelola destinasi. Dikarenakan atraksi sudah tidak menarik penduduk membangun fasilitas non pariwisata sehingga destinasi yang tua mengalami kekumuhan dan terjadi degradasi lingkungan. Namun apabila pada tahap stagnation pngelola investor melakukan peremajaan atraksi dan fasilitas yang 
lebih artivisual hal ini dapat menambah dayatraik destinasi wisata sehingga jumlah kunjungan kembali meningkat dan destinasi terhindar dari degradasi lingkungan.

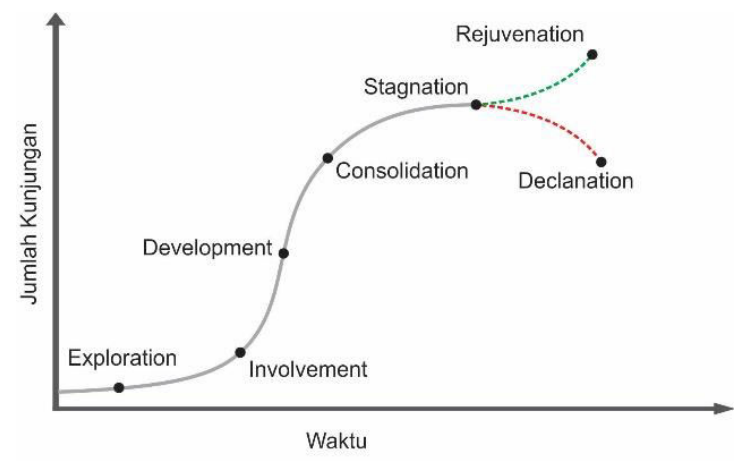

Gambar 1. Siklus Tourism Area Life Cycle

Sumber : (Pranata, 2018)

Adapun hasil penelitia (Pranata, 2018) menunjukkan bahwa dari kelima taman wisata di sepanjang Sungai Kalimas tiga diantaranya berada pada tahap development yakni Taman Wisata Prestasi, Ekspresi, dan Jayengrono. Sedangkan dua lainnya berada pada tahap consolidation yakni Taman Wisata Keputran, dan BMX \& Skate. Karakteristik Taman Wisata Keputran dan BMX \& Skate yang berada pada tahap consolidation menunjukkan turunnya performa dayatarik pada taman wisata. Apabila kondisi tersebut dibiarkan maka taman wisata dapat memasuki tahap stagnation dan declanation yang dapat menyebabkan degradasi lingkungan di Sungai Kalimas. Agar tidak terjadi degradasi lingkungan kembali pada kawasan Sungai Kalimas, perlu dirumuskan strategi strategi pengembangan taman wisata berdasarkan tourism area lifec cycle agar dapat mendukung program revitalisasi di Sungai Kalimas Surabaya.

\section{METODE PENELITIAN}

A. Jenis dan Pendekatan Penelitian

Pendekatan yang digunakan dalam penelitian ini adalah pendekatan rasionalistik. Jenis penelitian dalam penelitian ini adalah deskriptif kualitatif (Sasongko, 2002)

B. Variabel Penelitian

Variabel yang digunakan untuk merumuskan strategi pengembangan taman wisata adalah variabel dalam Tourism Area Life Cycle pada penelitian ini yang teridiri dari aspek fungsi taman [6]-[7] dan komponen pariwisata [8]-[9] sehingga didapatkan variabel pengelola, atraksi, sarana dan prasarana, aksesibilitas, upaya promosi, dan pengunjung.

Tabel 1. Variabel Aspek Fungsi Taman

\begin{tabular}{|l|l|l|}
\hline Indikator & Variabel & Definisi Operasional \\
\hline
\end{tabular}




\begin{tabular}{|l|l|l|}
\hline Fungsi Lingkungan & Vegetasi Taman & $\begin{array}{l}\text { Jenis vegetasi yang } \\
\text { memberikan efek teduh dan } \\
\text { keasrian taman }\end{array}$ \\
\hline Fungsi Sosial & Sarana Sosial & $\begin{array}{l}\text { sarana untuk berinteraksi } \\
\text { sosial }\end{array}$ \\
\hline Fungsi Estetika & $\begin{array}{l}\text { Perpaduan jenis ragam } \\
\text { vegetasi yang ditanam pada } \\
\text { taman }\end{array}$ \\
\cline { 3 - 3 } & Penataan Vegetasi & $\begin{array}{l}\text { Cirikhas penataan taman dari } \\
\text { taman lainnya }\end{array}$ \\
\hline
\end{tabular}

Sumber: dioalah dari berbagai sumber

Tabel 2. Variabel Aspek Komponen Pariwisata

\begin{tabular}{|c|c|c|}
\hline Indikator & Variabel & Definisi Operasional \\
\hline \multirow[t]{2}{*}{ Kelembagaan } & \multirow[t]{2}{*}{ Lembaga pengelola } & $\begin{array}{l}\text { Pihak yang bertanggung } \\
\text { jawab mengelola taman }\end{array}$ \\
\hline & & $\begin{array}{l}\text { Perean pengelola dalam } \\
\text { mengelola taman }\end{array}$ \\
\hline \multirow[t]{3}{*}{$\begin{array}{l}\text { Atraksi dan obyek daya tarik } \\
\text { wisata }\end{array}$} & $\begin{array}{l}\text { Adanya atraksi yang dapat } \\
\text { dilihat (something to see) }\end{array}$ & $\begin{array}{l}\text { Pemandangan alami berupa } \\
\text { vegetasi dan penataan } \\
\text { estetika yang dapat } \\
\text { dilihat/dinikmati }\end{array}$ \\
\hline & $\begin{array}{l}\text { Atraksi yang dapat dilakukan } \\
\text { (something tp do) }\end{array}$ & $\begin{array}{l}\text { Aktivitas yang dapat } \\
\text { dilakukan melalui sarana } \\
\text { sosial yang tersedia pada } \\
\text { taman }\end{array}$ \\
\hline & $\begin{array}{l}\text { Produk yang dapat dibeli } \\
\text { (something to buy) }\end{array}$ & $\begin{array}{l}\text { Produk cirikhas pada taman } \\
\text { yang dapat dibeli sebagai } \\
\text { kenang-kenangan }\end{array}$ \\
\hline \multirow[t]{4}{*}{ Fasilitas } & Sarana Rekreasi & $\begin{array}{l}\text { kondisi sarana yang } \\
\text { menunjang atraksi taman } \\
\text { wisata (fungsi lingkungna, } \\
\text { sosial dan fungsi estetika) }\end{array}$ \\
\hline & Sarana Penjualan & $\begin{array}{l}\text { kondisi sarana yang } \\
\text { digunakan untuk menunjang } \\
\text { penjualan produk cirikhas }\end{array}$ \\
\hline & Sarana Sanitasi & kondisi toilet yang tersedia \\
\hline & Sarana Ibadah & kondisi sarana peribatan \\
\hline \multirow[t]{3}{*}{ Infrastruktur (prasarana) } & Listrik & $\begin{array}{l}\text { kondisi aliran listrik di wisata } \\
\text { taman kota }\end{array}$ \\
\hline & Air Bersih & $\begin{array}{l}\text { kondisi air bersih di wisata } \\
\text { taman kota }\end{array}$ \\
\hline & Drainase & kondisi saluran darainase di \\
\hline
\end{tabular}




\begin{tabular}{|l|l|l|}
\hline & & wisata taman kota \\
\cline { 2 - 3 } & Sistem Persampahan & $\begin{array}{l}\text { kondisi sistem persampahan } \\
\text { di wisata taman kota }\end{array}$ \\
\hline Aksesibilitas & Transportasi umum & $\begin{array}{l}\text { kondisi transportasi umum } \\
\text { seperti yang melintas di } \\
\text { taman wisata }\end{array}$ \\
\cline { 2 - 3 } & Prasarana transportasi & $\begin{array}{l}\text { kondisi tempat parkir taman } \\
\text { wisata }\end{array}$ \\
\hline Promosi & Upaya promosi & $\begin{array}{l}\text { Media yang digunakan untuk } \\
\text { menginfotmasikan taman } \\
\text { wisata }\end{array}$ \\
\cline { 3 - 3 } & $\begin{array}{l}\text { jangkauan penyebaran } \\
\text { informasi }\end{array}$ \\
\hline Pengunjung & $\begin{array}{l}\text { Trend jumlah kunjungan } \\
\text { dalam 1 tahun, apakah } \\
\text { meningkat, menurun, atau } \\
\text { stagnan }\end{array}$ \\
\hline
\end{tabular}

Sumber: dioalah dari berbagai sumber

\section{Metode Pengumpulan Data}

Pengumpulan data dilakukan melalui survei sekunder dimana pengeumpulan data yang tidak dilakukan secara langsung di lapangan. Survei sekunder dilakukan melalui survei literatur yang teridir dari data hasil penelitian (Pranata, 2018) mengenai tipologi Tourism Area Life Cycle taman wisata di Sungai Kalimas serta kebijakan mengani rencana penataaan dan revitalisasi Sungai Kalimas sebagai acuan strategi pengembangan.

\section{Metode dan Teknik Analisis}

Perumusan strategi pengembangan taman wisata kalimas dilakukan melalui analisis SWOT dengan memilah kakrakteristik taman wisata kalimas dan program revitalisasi kalimas ke dalam matriks dengan kategori Strenght (S) atau kekuatan, Weakness (W) atau kelemahan, Opportunity (O) atau peluang, dan Treath $(\mathrm{T})$ atau ancaman. Strategi pengembangan didapatkan dengan membangdingkan matriks (SO), (WO), (ST), dan (WT) (Rangkuti, 1997). Tahapan siklus hidup yang diacu untuk pengembangan adalah pada tahapan development dan rejuvenation, hal ini dikarenakan pada tahap ini merupakan tahap dimana jumlah kunjungan meningkat secara signifikan dengan komponen pariwisata yang masih menarik wisatawan.

Tabel.3 Matriks SWOT

\begin{tabular}{|l|l|l|}
\hline & Streght (S) & Weaknes (W) \\
\hline Opportunity (O) & Strategi S-O & Strategi W-O \\
\hline
\end{tabular}




\begin{tabular}{|l|l|l|}
\hline Treath (T) & Strategi S-T & Strategi W-T \\
\hline
\end{tabular}

Sumber : (Rangkuti, 1997)

\section{HASIL DAN DISKUSI}

Penelitian ini dilakukan pada taman wisata di bantaran sungai kalimas yang termasuk taman hasil revitalisasi revitalisasi dan menjadi objek wisata kota. Taman tersebut diantaranya adalah Taman Wisata Keputran, Taman Wisata BMX \& Skate, Taman Wisata Prestasi, Taman Wisata Ekspresi, dan Taman Wisata Jayengrono.

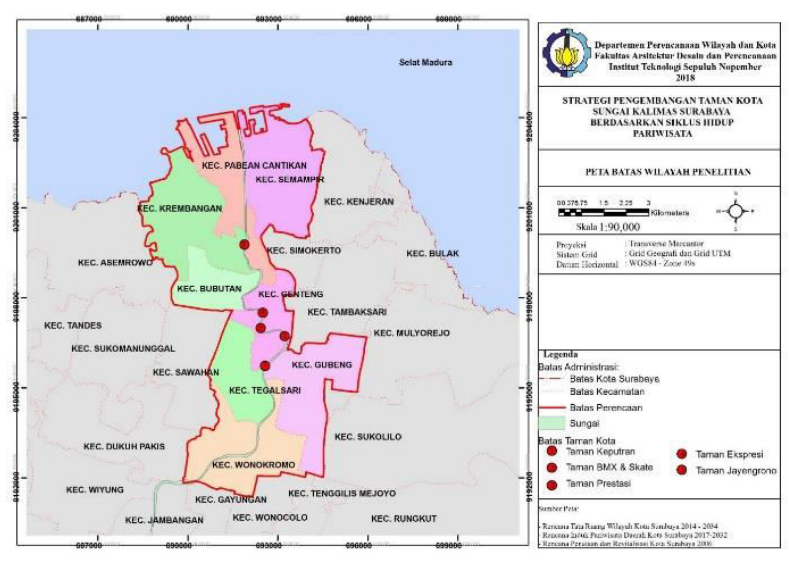

Gambar 1. Peta Lokasi Taman Wisata Kalimas

Sumber: (Pranata, 2018)

\subsection{Strategi Pengembangan Tw. Keputran}

Berdasar hasil penelitian (Pranata, 2018) karakteristik TALC TW. Keputran berada pada tahap consolidation. Secara umum, TW. Keputran menunjukkan pada tahap consolidation dikarenakan wisatawan yang menginginkan untuk pembangunan atraksi baru agar taman lebih menarik serta sedikitnya jumlah kunjungan dan kenaikan kunjungan yang tidak signifikan. Apabila digolongan berdasarkan strenght, weakness, opportunity, dan treath maka karakteristik yang menjadi strenght atau kekuatan TW. Keputran diantaranya adalah terbangunnya atraksi alami dan buatan dengan atraksi alami lebih menarik. Selain itu juga tersedia sarana prasarana rekreasi dengan kondisi terawat dan tidak ada dampak negatif. Destinasi juga dilengkapi tempat parkir roda 2 dan roda 4 yang masih memadai serta secara keseluruhan desitnasi dikelolah oleh Dinas Kebersihan dan Ruang Terbuka Hijau (DKRTH) yang masih berperan.

Adapun kelemahan atau weakness dari TW. Keputran diantaranya adalah sarana sanitasi yang masih portable, serta tidak ada sarana peribadatan dan sarana penjualan. Upaya promosi juga hanya sebatas melalui leaflat serta penyebaran tidak terjadwal dan tertarget. 
Peluang atau oportunity yang dimiliki TW. Keputran diantaranya adalah terbangunnya jalan aspal menuju taman dengan kondisi baik serta trersedia transportasi umum berupa lyn. Meski demikian wisatawan menuju taman dengan kendaraan pribadi. Selain itu juga terdapat pasar keputran yang menjadi tujuan utama wisatawan mengunjungi kawasan tersebut. Peluang juga didapatkan dari Indikasi Program Kawasan Peneleh-Genteng dalam Dokumen Rencana Penataan dan Revitaliasai Sungai Kalimas (B. P. P. K. Surabaya, 2006) yang terdiri dari tema pengembangan taman berupa "Taman dan Ruang Publik Tepi Sungai", pengembangan/ pembangunan Promenade sungai yang nyaman bagi pejalan kaki sebagai penghubung daerah CBD dan daerah utara mengembangkan Taman Linier dan koneksi ruang terbuka serta mengembangkan niaga tepi sungai (restoran dan pusat perbelanjaan).

Adapun yang menjadi ancaman atau treath di TW. Keputran diantaranya adalah adanya pengunjung yang memancing, mandi, dan buang air di bagian taman tepi sungai. Selain itu wisatawan bosan dengan atraksi sehingga jumlah kunjungan sedikit, serta meningkat tidak signifikan. Wisatawan teridiri hanya dari orang-orang sekitar dengan tujuan ada keperluan di pasar keputran. Hal lain yang menjadi ancaman adalah wisatawan tidak mengetahui informasi tentang taman wisata keputran serta tidak pernah ada peminjaman taman untuk kegiatan.

Agar dayatarik TW. Keputran dapat kembali optimal, maka dirumuskan strategi dengam mengomparasikan kondisi strenght dengan opportunity (SO), weakness dengan opportunity (WO), strenght dengan treath (ST), dan weakness dengan treath (WT). Adapaun stratgei SO dari TW. Keputran diantaranya adalah dengan mengusung tema Mengusung tema pengembangan TW. Keputran dengan nuansa pasar tradisional agar selaras dan terintegrasi pasar keputran. Serta agar selaras dengan pasar tradisional dan menambah daya tarik destinasi perlu dilakukan penambahan atraksi buatan berupa spot untuk mainan bertemakan tradisional diantaranya congklak dengan ukuran besar, engklek/bendan, dan alat musik tradisional seperti angklung dan gamelan. Selain itu perlu juga dilakukan perawatan seluruh atraksi dan sarana prasarana yang terdapat di TW. Keputran.

Adapun strategi W-O yang dapat dilakukan diantaranya adalah pembangunan sarana sanitasi kamar mandi permanen serta sanara ibadah. Selain itu juga dapat ditambahkan stand bazar pasar tradisional setiap hari minggu, dengan menjual olahan komoditas keputran untuk menciptakan kegiatan niaga di sepanjang kalimas.

Untuk meminimalisir ancaman melalui kekuatan yang dimiliki maka strategi S-T yang dapat dilakukan di TW. Keputran diantaranya adalah meningkatkan peggawasan pada pengunjung yang tidak mengfungsikan taman sebagai mana mestinya. Selain itu agar lebih mendatangkan wisatawan dapat dengan menanam sayuran yang dijual di pasar keputran secara hidroponik disertai infografis manfaat dari setiap sayuran, diadakan event petik sayur setiap panen sayuran yang ditanam, serta mengadakan acara lomba atau demo memasak setiap bulan berbahan dasar komoditas yang dijual di Pasar Keputran. Adapun untuk strategi W-T adalah dengan membuat akun mediasosial serta menyusun upaya promosi yang terjadwal dan rutin untuk memperluas jangkauan wisatawann. 


\subsection{Strategi Pengembagnan Tw. Bmx \& Skate}

Berdasar hasil penelitian (Pranata, 2018) karakteristik TALC TW. BMX \& Skate Berada pada tahap consolidation. Secara umum, taman Keputran menunjukkan pada tahap consolidation dikarenakan beberapa sarana ditemukan kerusakan seperti arena skate berlubang dan jalan utama yang tidak terbangun, jumlah kunjungan yang tidak meningkat signifikan serta wisatawan juga menginginkan adannya atraksi baru. Secara lebih detail apabila digolongan berdasarkan strenght, weakness, opportunity, dan treath maka karakteristik dalam matriks SWOT TW. BMX \& Skate dapat dilihat pada tabel berikut :

Tabel 4. Matriks SWOT TW. BMX \& Skate

\begin{tabular}{|c|c|}
\hline $\begin{array}{l}\text { 1. Terbangunnya atraksi alami, buatan, dan event } \\
\text { 2. Atraksi buatan lebih ditonjolkan } \\
\text { 3. Atraksi buatan lebih menarik } \\
\text { 4. Terbangun sarana rekreasi, sanitasi, dan ibadah } \\
\text { 5. Tersedia prasarana listrik, air bersih, drainase, } \\
\text { dan sistem persampahan } \\
\text { 6. Kondisi sarana prasarana terawat } \\
\text { 7. Sarana prasarana tidak ada dampak negatif } \\
\text { 8. Dikelola resmi oleh DKRTH dan UPTD Taman } \\
\text { Rekreasi dan masih berperan }\end{array}$ & $\begin{array}{l}\text { 1. Asal wisatawan dari dalam kota, luar kota, dan } \\
\text { mancanegara } \\
\text { 2. Paling ramai dikunjungi hari sabtu } \\
\text { 3. Kunjungan wisatawan jumlah besar masih } \\
\text { ditemui } \\
\text { 4. Tersedia sentra PKL dikelola masyarakat } \\
\text { 5. Lokasi taman strategis diantara monkasel, Plaza } \\
\text { Surabayam dan WTC } \\
\text { 6. Kondisi jalan umum terawat } \\
\text { 7. Tersedia angkutan umum berupa lyn } \\
\text { 8. Terdapat dua jalan akses (utama dan alternatif) } \\
\text { 9. Kondisi jalan alterantif baik } \\
\text { 10. Tempat parkir jalan alternatif mencukupi } \\
\text { 11. Wisatawan menuju taman dengan kendaraan } \\
\text { pribadi } \\
\text { Indikasi Program Indikasi Program Kawasan } \\
\text { Peneleh-Genteng dalam Dokumen Rencana } \\
\text { Penataan dan Revitaliasai Sungai Kamlias Surabaya } \\
\text { (2006): } \\
\text { 12. Tema pengembangan "Taman dan Ruang } \\
\text { Publik Tepi Sungai" } \\
\text { 13. Pengembangan/ pembangunan Promenade } \\
\text { sungai yang nyaman bagi pejalan kaki sebagai } \\
\text { Tiesdell (1996): }\end{array}$ \\
\hline
\end{tabular}




\begin{tabular}{|c|c|}
\hline & $\begin{array}{l}\text { 16. Intervensi Fisik } \\
\text { 17. Rehabilitasi Ekonomi } \\
\text { 18. Revitalisasi Sosial }\end{array}$ \\
\hline $\begin{array}{l}\text { Weakness } \\
\text { 1. Tidak ada sarana penjualan } \\
\text { 2. Upaya promosi hanya melalui leaflat oleh } \\
\text { pengelola dan ulasan internet } \\
\text { 3. Promosi tidak terjadwal dan tidak tertarget } \\
\text { 4. Lahan yang terbatas untuk pengadaan atraksi } \\
\text { baru }\end{array}$ & $\begin{array}{l}\text { Treath } \\
\text { 1. Jumlah peminjaman taman meningkat tidak } \\
\text { signifikan } \\
\text { 2. Jumlah kunjungan meningkat tidak signifikan } \\
\text { 3. Wisatwan bosan dengan atraksi yang ada } \\
\text { 4. Kondisi jalan utama sempit dan rusak } \\
\text { 5. Tidak ada jawal promosi khusus } \\
\text { 6. Wisatawan belum tahu adanya promosi }\end{array}$ \\
\hline
\end{tabular}

Sumber: (Pranata, 2018)

Berdasarkan karateristik di atas, maka strategi pengembangan TW. BMX \& Skate agar destinasi memiliki performa yang lebih optimal agar tidak memasuki tahap yang dapat menyebabkan degradasi lingkungan. Melalui matriks S-O dapat dilakukan strategi berupa mengusung tema "Riverside Skate Park" sebagai cirikhas Taman Wisata BMX \& Skate agar menjadi cirikhas dari arena skate yang lain, serta menjadikan TW. BMX \& Skate sebagai pusat perkumpulan Skater di Surabaya.

Sedangkan untuk matriks W-O, peluang yang dapat diambil untuk mengatasi kelemahan TW. BMX \& Skate diantaranyaa adalah dengan bekerjasama dengan Dinas Koperasi untuk mengelolah sentra kuliner sehingga dapat dibangun sentra kuliner tepi sungai yang lebih artisitk dan terkoneksi dengan arena skateboard. Selain itu, pihak pengelolah juga dapat bekerjasama dengan pihak swasta untuk mendirikan toko skateboard sehingga Taman Wisata BMX dan Skate dapat menjadi pusat perkumpulan skateboard surabaya.

Untuk matriks S-T, kekuatan yang dapat digunakan untuk mengatasi ancaman pada TW. BMX \& Skate diantaranya dengan melakukan pengecatan pada arena taman secara berkala agar wisatawan mendapatkan suasana baru serta penambahan obstakel kecil di tepian taman. Selain itu juga melakukan renovasi pada jalan utama agar lebih walkable serta pembangunan tempat parkir roda 2 agar kendaraan lebih tertata. Agar dapat mendatangkan wisatawan baru, pengelolah dapat melakukan kolaborasi dengan komunitas skateboard Surabaya untuk membuat event skateboar rutin tiap bula serta bersama komunitas skateboard membuat kelas dan workshop skateboard agar menjaga wisatawan untuk tetap berkunjung ke TW. BMX \& skate.

Sedangkan dari matriks W-T agar dapat memperbaiki kelemahan dari ancaman, dapat dilakukan strategi diantaranya penambahan bangku taman untuk wisatawan menikmati atraksi skateboard sehingga tidak hanya pengguna skateboard saja yang dapat menikmati taman, namun juga wisatawan yang ingin menyaksikan aktivitas skateboard juga terfasilitasi. Selain itu juga pengelola perlu membuat akun mediasosial serta menyusun upaya promosi yang terjadwal dan rutin agar dapat menjangkau wisatawan lebih banyak. 


\subsection{Strategi Pengembagnan Tw. Prestasi}

Dalam penelitian (Pranata, 2018) disebutkan bahwa TALC TW. Prestasi berada pada tahap development. Secara umum karakateristik TW. Prestasi yang menunjukkan pada tahap development diantaranya adalah kondisi sarana yang terawat, jumlah kunjungan yang meningkat signifikan, serta tidak adanya permintaan atraksi baru oleh wisatawan karena dianggap masih diminati khususnya atraksi alami masih lebih diminati daripada atraksi buatan. Secara lebih detail apabila digolongan berdasarkan strenght, weakness, opportunity, dan treath maka karakteristik dalam matriks SWOT TW. BMX \& Skate dapat dilihat pada tabel berikut :

\section{Tabel 5. Matriks SWOT TW. Prestasi}

\begin{tabular}{|c|c|}
\hline $\begin{array}{l}\text { Streght } \\
\text { 1. Terbangun atraksi alami, buatan, dan event } \\
\text { 2. Atraksi alami lebih dimanati } \\
\text { 3. Tersedia sarana rekreasi, sanitasi, ibadah, dan } \\
\text { penjualan } \\
\text { 4. Tidak ada dampak negatif dari sarana } \\
\text { 5. Tersedia tempat parkir roda } 2 \text { dan roda } 4 \text { yang } \\
\text { memadai } \\
\text { 6. Taman dikelola resmi oleh DKRTH dan UPTD } \\
\text { Taman Rekreasi yang masih berperan }\end{array}$ & $\begin{array}{l}\text { Opportunity } \\
\text { 1. Jumlah pemninjaman taman meningkat } \\
\text { signifikan } \\
\text { 2. Jumlah kunjungan wisatawan meningkat } \\
\text { signifikan } \\
\text { 3. Wisatawan berasal dari dalam kota, luar kota, } \\
\text { manca negara } \\
\text { 4. Kunjungan wisatawan paling ramai akhir pekan } \\
\text { 5. Tersedia jalan umum ketabang kali dengan } \\
\text { kondisi baik } \\
\text { 6. Wisatawan menggunakan kendaraan pribadi } \\
\text { Indikasi Program Indikasi Program Kawasan } \\
\text { Peneleh-Genteng dalam Dokumen Rencana } \\
\text { Penataan dan Revitaliasai Sungai Kamlias Surabaya } \\
\text { (2006): } \\
\text { 7.Tema pengembangan "Taman dan Ruang Publik } \\
\text { Tepi Sungai" } \\
\text { 8. Pengembangan/ pembangunan Promenade } \\
\text { sungai yang nyaman bagi pejalan kaki sebagai } \\
\text { penghubung daerah CBD dan daerah utara } \\
\text { 9. Mengembangkan Taman Linier dan koneksi } \\
\text { ruang terbuka natrangan (restoran } \\
\text { 10.Mengembangkan niaga tepi sungai perbelanjaan) } \\
\text { Tiesdell (1996): } \\
\text { 11. intervensi Fisik } \\
\text { 12. Rehabilitasi Ekonomi } \\
\text { 13. Revitalisasi Sosial }\end{array}$ \\
\hline Weakness & Treath \\
\hline
\end{tabular}




\begin{tabular}{|l|l|}
\hline $\begin{array}{l}\text { 1. Media promosi hanya berupa leaflat dan ulasan } \\
\text { situs diinternet }\end{array}$ & $\begin{array}{l}\text { 1. Tidak tersedia transportasi umum } \\
\text { 2. Jauhnya jarak sentra pkl dengan lokasi taman } \\
\text { wisata }\end{array}$ \\
& $\begin{array}{l}\text {. Adanya pedagang asongan yang berjualan tiap } \\
\text { hari di tepi jalan dan hari minggu di dalam jalan } \\
\text { yang terlihat tak tertata }\end{array}$ \\
& $\begin{array}{l}\text { 3. Wisatawan tidak mengetahui adanya promosi } \\
\text { 4. Promosi tidak terjadwal }\end{array}$ \\
\hline
\end{tabular}

Sumber: (Pranata, 2018)

Berdasarkan karakteristik di atas, maka strategi pengembangan TW. Prestasi dirumuskan agar dapat mempertahankan performa optimalnya. Melalui matriks S-O dapat dilakukan strategi brupa memanfaatkan kekuatan yang dimiliki dalam mengambil peluang diantaranya adalah dengan mengusung tema olahraga air sebagai ciri khas Taman Wisata Prestasi serta menjadikan taman wisata prestasi sebagai pusat wisata air sungai di Surabaya melalui event olahraga air rutin setiap minggu dan event besar setiap bulan event lomba dayung tingkat provinsi setiap tahunnya. Seta. Pengelola juga dapat memperpanjang jam buka wisata air hingga malam hari pukul 22.00 pada akhir pekan agar wisatawan dapat menikmati wisata air dengan memberikan hiasan lampu warna-warni pada perahu untuk lebih menarik ketika beroperasi di malam hari.

Selain melalui kekuatan, kelemahan juga dapat diatasi dengan memanfaatkan peluang dimana yang dirumuskan melalui matriks W-O. adapun strateginya dapat berupa menyediakan layanan delivery service pada wisatawan yang sedang menikmati taman. Tujuannya adalah agar wisatawan lebih mudah membeli produk yang disediakan sentra pkl yang tersedia.

Untuk meminimalisir ancaman, strategi disusun berdasarkan kekuatan yang dimiliki untuk mengatasi ancaman melalui matriks S-T. Adapun strategi pada matriks ini diantaranya adalah bekerjasama dengan pihak Surabaya Tour dikarenakan tidak adanya transportasi umum yang melintas, sehingga diharapkan TW. Prestasi menjadi salahsatu destinasi yang dituju wisatawan melalui bus Surabaya Tour. Selain itu juga menertibkan pedagang asongan dan mengarahkan wisatawan untuk membeli makanan dan minuman pada sentra kuliner yang tersedia agar kegiatan perniagaan di TW. Prestasi menjadi lebih tertib.

Sedangkan untuk mengatasi kelemahan dan ancaman, melalui matriks $\mathrm{W}-\mathrm{T}$ dapat disusun strategi berupa membuat akun mediasosial serta menyusun upaya promosi yang terjadwal dan rutin untuk memperluas jangkauan wisatawan. Selain itu strategi ini juga agar wisatawan mengetahui informasi terbaru mengenati TW. Prestasi sehingga tetap tertarik untuk mengunjungi.

\subsection{Strategi Pengembagnan Tw. Ekspresi}

Hasil penelitian (Pranata, 2018) menunjukkan bahwa TALC TW. Ekspresi berada pada tahap development. Hal ini dikarenakan secara umum TW. Ekspresi memiliki karakteristik jumlah kunjungan masih meningkat meski tidak signifikan namun ada kunjungan dalam jumlah besar, terbangunnya atraksi dengan saran prasarana terawat serta tidak adanya permintaan atraksi baru dari wisatawan karena masih diminati khususnya atraksi alami masih lebih diminati daripada atraksi buatan. Sedangkan secara 
lebih detail apabila digolongan berdasarkan strenght, weakness, opportunity, dan treath maka karakteristik dalam matriks SWOT TW. BMX \& Skate dapat dilihat pada tabel berikut :

Tabel 6. Matriks SWOT TW. Ekspresi

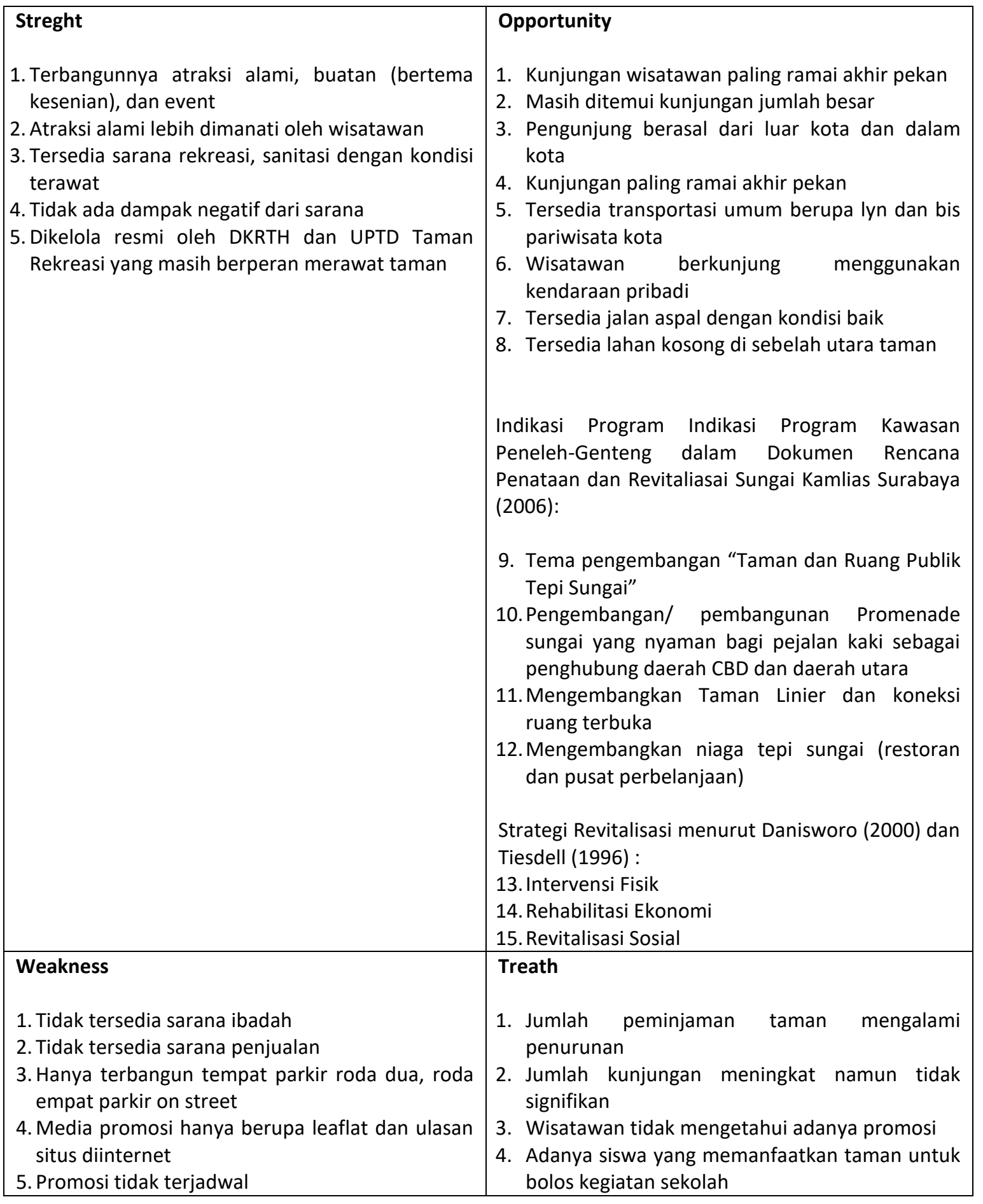


Sumber: (Pranata, 2018)

Melalui karakteristik di atas dirumuskan strategi pengembangan agar TW. Ekspresi tetap memiliki performa yang optimal. Dari matriks S-O dirumuskan strategi berdasrkan kekuatan yang dimiliki untuk mengambil peluang yang tersedia, strategi ini diantaranya dengan menjadikan tema kesenian sebagai cirikhas Taman Wisata Ekspresi serta menjadikan Taman Wisata Ekspresi sebagai salah satu pusat sarasehan karyaseni dengan menggandeng seninam seniman Surabaya. Melalui hal tersebut kedepannya perlu diadakan event-event berupa sayembara karya seni rupa dan memanfaatkan sebagai ornamen penghias taman secara berkala. Hal ini bertujuan agar atraksi dan kegiatan yang terdapat di TW Ekspresi sesuai dengan namanya yakni tempat untuk berekspresi karya seni, sehingga menjadi cirikhas dan dayatarik tersendiri.

Untuk kelemahan dari TW. Ekspresi yang dapat diatasi dengan peluang dirumuskan melalui matriks W-O. adapun strategi pengembangannya diantaranya adalah Stratgi W-O Pembangunan sarana ibadah agar wisatawan tidak terlalu jauh mencari tempat ibadah. Selain itu pengelolah juga bisa memanfaatkan lahan kosong di sisi utara taman wisata ekspresi sebagai tempat parkir roda empat serta sarana penjualan baik makanana dan minuman maupun cinderamata kesenian \& Membuat papan informasi lokasi parkir on street untuk Roda sehingga menambah pada TW. Ekspresi memiliki atraksi sesuatu yang dapat dibeli (what to buy attraction).

Untuk meminimalisir ancaman di TW. Ekspresi dapat diatasi dengan memanfaatkan kekuatan. Strategi ini didapatkan melalui matriks S-T yang diantaranya dengan menggandeng seniman seniman Surabaya untuk mengadakan event rutin di taman Wisata Ekspresi, seperti pameran seni rupa, baca dan bedah puisi, teaterikal monolog, live music dll. Selain itu juga dapat menggandeng komunitas-komunitas seni Surabaya untuk melakukan diskusi di Taman Wisata Ekspresi serta membuat event rutin pameran karya seni untuk mempromosikan karya seni khususnya seniman-seniman Surabaya. Strategi ini dirumuskan agar TW. Ekspresi tetap dapat mendatangkan wisatawan dengan keigatan yang sesuai dengan TW. Ekspresi.

Sedangkan agar meminimalisir ancaman beserta kelemahan, strategi disusun pada matriks W-T. strategi ini berupa membuat akun mediasosial serta menyusun upaya promosi yang terjadwal dan rutin untuk memperluas jangkauan wisatawan. Hal ini agar informasi mengenai TW. Ekspresi dapat disebarkan dan dapat mendatangkan wisatawan.

\subsection{Strategi Pengembagnan Tw. Jayengrono}

Hasil penelitian (Pranata, 2018) menunjukkan bahwa TW. Jayengrono berada pada tahap TALC development. Secara umum karakteristik yang menunjukkan TW. Jayengrono berada pada tahap development diantaranya adalah terbangunnya atraksi dengan sarana dan prasarana terawat, jumlah kunjungan masih meningkat meski tidak signifikan serta tidak adanya permintaan atraksi baru oleh wisatawan karena masih diminati khususnya atraksi alami masih lebih diminati daripada atraksi buatan. 
Secara lebih detail apabila digolongan berdasarkan strenght, weakness, opportunity, dan treath maka karakteristik dalam matriks SWOT TW. BMX \& Skate dapat dilihat pada tabel berikut :

Tabel 7. Matriks SWOT TW. Jayengrono

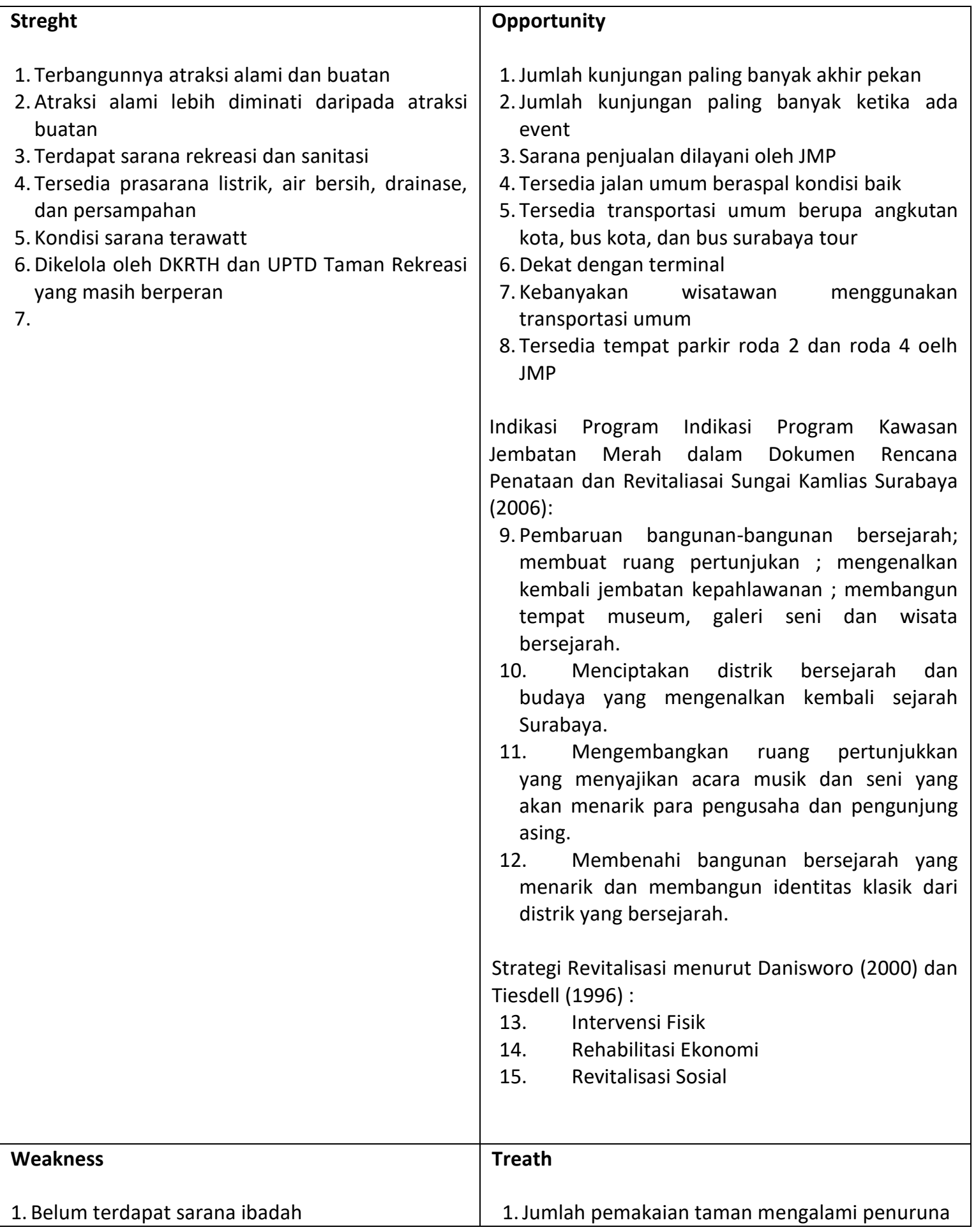


2. Hanya tersedia tempat parkir untuk roda dua

3. Media promosi berupa leaflat dan ulasan situs diinternet
2. Jumlah meningkat namun tidak signifikan

3. Promosi tidak terjadwal

Wisatawan tidak mengetahui adanya promosi

Sumber: (Pranata, 2018)

Melalui karakteristik di atas dirumuskan strategi pengembangan agar TW. Jayengrono tetap memiliki performa yang optimal. Dari matriks S-O dirumuskan strategi berdasrkan kekuatan yang dimiliki untuk mengambil peluang yang tersedia, strategi ini diantaranya dengan mengembangkan tema taman sejarah yang telah diusung sebagai cirikhas Taman Wisata Jayengrono serta menjadikan area tengah Taman Wisata Jayengrono sebagai ruang pertunjukkan untuk karya seni. Hal ini bertujuan agar TW. Jayengrono yang berlokasi di kawasan Jembatan Merah dapat menjadi taman yang mengenang perjuangan arek-arek Suroboyo dalam melawan penjajah di jembatan merah.

Untuk kelemahan dari TW. Jayengrono yang dapat diatasi dengan peluang dirumuskan melalui matriks W-O. Adapun strategi pengembangannya diantaranya adalah pembangunan sarana ibadah agar dapat memfasilitasi wisatawan yang hendak beribadah. Selain itu juga Pihak pengelola TW. Jayengrono dan pihak JMP dapat bekerjasama mejadikan tempat parkir JMP sebagai tempat parkir wisatawan TW. Jayengrono juga, hal ini dikarenakan tidak tersedianya tempat parkir di TW. Jayengrono.

Untuk meminimalisir ancaman di TW. Ekspresi dapat diatasi dengan memanfaatkan kekuatan. Strategi ini didapatkan melalui matriks S-T yang diantaranya dengan mengadakan event live music setiap malam minggu serta mengadakan event pertunjukkan teaterikal bersejarah setiap bulannya, khusussnya untuk mengenang perjuangan arek-arek Suroboyo. Hal ini bertujuan agar wisatawan tetap tertarik mengunjugi TW. Jayengrono dengan suguhan atraksi yang bertemakan taman tersebut. Selain itu bisa juga mengadakan event pemutaran film-film sejarah perjuangan arek-arek Suroboyo untuk mengenang dan mengedukasi masyarakat mengenai perjuanagan pemuda Surabaya, diputar setiap minggu.

Sedangkan agar meminimalisir ancaman beserta kelemahan, strategi disusun pada matriks W-T. strategi ini berupa membuat akun mediasosial serta menyusun upaya promosi yang terjadwal dan rutin untuk memperluas jangkauan wisatawan. Hal ini agar informasi mengenai TW. Jayengrono dapat disebarkan dan dapat mendatangkan wisatawan.

\section{KESIMPULAN}

Adapun kesimpulan dari penelitian ini adalah sebagai berikut :

1. Berdasar karakteristiknya terdapat dua tipologi tahapan TALC yakni Development dan Consolidation. Tahap Development terdiri dari taman wisata Prestasi, Ekspresi, dan Jayengrono. Tahap Consolidation terdiri dati taman wisata Keputran dan BMX \& Skate

2. Taman wisata dengan tahap development memiliki ciri terbangunnya atraksi beserta sarana prasarana yang masih menarik bagi wisatawan sehingga jumlah kunjungan wisatawan selalu meningkat signifikan. Karena atraksi yang masih menarik, maka agar menjaga jumlah kunjungan 
tetap meningkat strategi pengembangan condong hanya dengan pengadaan event yang selaras dengan tema pengembangan taman.

3. Taman wisata dengan tahap consolidation memiliki ciri atraksi beserta sarana parasarna terbangun yang menurut wisatawan membosankan, sehingga jumlah kunjungan meningkat namun sudah tidak signifikan. Agar dapat menarik kembali wisatawan, strategi pengembangan dilakukan dengan pembangunan atraksi baru dan pengadaan event yang selaras dengan tema pengembangan

\section{DAFTAR PUSTAKA}

Pitana, I. G. (2009). Pengantar Ilmu Pariwisata. yogyakarta: C.V ANDI OFFSET.

Pranata, G. (2018). Strategi Pengembangan Wisata Taman Kota Berdasarkan Siklus Hidup Pariwisata Di Sungai Kalimas Surabaya. surabaya.

Rangkuti, F. (1997). Teknik Membedah Kasus Bisnis Analisis SWOT. Jakarta: PT Gramedia Jakarta Utama.

Sasongko, P. D. (2002). Kajian Perubahan Fungsi Taman Kota di Semarang. Semarang.

Surabaya, B. P. P. K. Rencana Penataan dan Revitalisasi Sungai Kalimas (2006).

Surabaya, D. K. dan P. K. Rencana Induk Pariwisata Kota Surabaya tahun 2017-2032 (2017). 